\title{
Phagocytosis in Leprosy I. The Levels of "Diaphorase", $\beta$-Glucuronidase, Acid Phosphatase, Alkaline Phosphatase and Lipase in Circulating Leucocytes
}

\author{
J. E. GARCIA-GONZALEZ, O. ROJAS-ESPINOSA* AND \\ S. ESTRADA-PARRA
}

Departamento de Inmunologia, Escuela Nacional de Ciencias Biológicas, Instituto Politécnico Nacional, México, D.F., México

\begin{abstract}
Peripheral blood leucoytes were obtained from 18 patients with active lepromatous leprosy and 18 healthy volunteers. These cells were disrupted and served as the source of $\beta$-glucuronidase, $\beta$-galactosidase, acid phosphatase, alkaline phosphatase and lipase activities. A quantitative NBT test was performed with freshly prepared intact cell suspensions. Although most of the studied activities were slightly increased in the leprosy group, the differences resulted in non-statistical significance. Other enzymatic and metabolic activities have to be studied to corroborate that leucocytes from leprosy patients behave in an essentially normal manner.
\end{abstract}

\section{Introduction}

Phagocytosis of pathogenic bacteria is a first line mechanism for the host defense. Endocytosis itself, however, is not enough for the control of disease unless it is followed by the normal metabolic and bactericidal changes induced within the phagocytic cell. Some pathological situations have been explained on the basis of metabolic defects which impair the phagocytes' function even when endocytosis seems to be normal (Stossel et al., 1972; Kaplan et al., 1968; Holmes et al., 1967; Cooper et al., 1972, among others). However, most of these situations seem to have an intrinsic defect rather than being the result of an induced impairment due to some external aetiological agent of disease.

Lepromatous leprosy is an interesting disease because, among other things, some reports have appeared suggesting that the difficulty in controlling the disease could be explained on the basis of a defect in the function of the host's macrophages (Beiguelman, 1967; Barbieri and Correa, 1967; Hanks, 1947; Convit

*Address correspondence and offprint requests to: Dr O. Rojas-Espinosa, Departamento de Inmunología, Escuela Nacional de Ciencias Biológicas, Instituto Politécnico Nacional. Apartado Postal 17-605, México 17, D.F., México.

Received for publication 4 November 1976. 
et al., 1972, 1974). This defect could be a primary one, induced by interference of the phagocytic cell metabolism by the mycobacterial metabolism, or it could be the result of a lack of T-lymphocyte-dependent macrophage stimulation (Godal et al., 1971a,1971b), as it has been shown that patients. with lepromatous leprosy have a depressed cell-mediated immunity: low numbers of direct rosettes (circulating T-lymphocytes) (Dwyer et al., 1973; Lim et al., 1974a), depressed ability to reject allogeneic skin grafts (Job and Karat in Hart and Rees, 1967), anergy to M. leprae antigens (Mitsuda, 1953), and other aberrations in the cellular immunity (Turk, 1969; Turk and Waters, 1969).

When an impairment in phagocytic function is suspected to play a role in a given pathological state, it could be normative to survey the activity of the whole phagocytic population before attempting to analyze the function of a particular type of cell. As this is the case in lepromatous leprosy it was decided to study some metabolic and enzymatic activities in blood leucocyte populations (in which about $80 \%$ are phagocytic cells) prepared from a number of patients with the disease and compare such activities with those found in cell preparations from healthy individuals. The study of leucocytes was also decided because viable blood-borne $M$. leprae have been found in circulating phagocytes from patients with lepromatous leprosy who have received no chemotherapy. Intracellular parasites whose viability has not been definitively ruled out have also been observed in leucocytes from patients treated with dapsone or rifampin (Drutz et al. , 1974).

As polymorphonuclear (PMN) leucocytes are the predominant cell type in peripheral blood, the results will be largely indicative of the activity of these cells, but the possibility remains that some defect (if any) in another cell type (i.e. the monocyte) may reflect in the overall activity of the complete leucocyte population.

\section{Materials and Methods}

\section{SUBJECTS}

Eighteen patients with polar lepromatous leprosy (both diffuse and nodular types of leprosy included) were studied. This group has been under medical control at the Centro Dermatológico Pascua of Mexico City, and represented an heterogeneous group in relation to age, sex, duration of disease and clinical status at the moment of the study. Most of the patients, however, were under conventional treatment (DDS, $25-50 \mathrm{mg}$ daily) and all of them presented a still active form of the disease. A very few cases were complicated with some form of leprosy reaction (mainly erythema nodosum leprosum).

Eighteen healthy volunteers (personnel and undergraduate students) with no familial antecedents of mycobacterial disease (leprosy or tuberculosis) of both sexes, and with an average age of 24 years, served as controls.

\section{CELL PREPARATIONS}

About $200 \mathrm{ml}$ of blood was collected in blood collection units with citrate as the anticoagulant (Bolsang, Fenwal System, CPD, Travenol Laboratories, Costa Mesa, California, U.S.A.). The citrate-treated blood was transferred to siliconized glass cylinders and left undisturbed to sediment at $37^{\circ} \mathrm{C}$ for $120 \mathrm{~min}$. The leucocyte-rich plasma was aspirated, poured into siliconized glass centrifuge bottles, treated with 2 vols of $0.87 \%$ ammonium chloride to disrupt erythrocytes, washed twice with citrate-saline solution (CSS, $0.4 \%$ sodium citrate in $0.85 \%$ sodium chloride), resuspended in about $10 \mathrm{ml}$ of CSS, counted in a haemocytometer (differential counts were done in smears stained with Wright's dye), quick frozen and stored at $-70^{\circ} \mathrm{C}$ until used. 
Just before their use, the cell suspensions were thawed, diluted as required, briefly sonicated to disperse aggregates (30 s, $7 \mathrm{~mA}$, d.c.) in a S-125 Sonifier (Branson Sonic Power, Denbury, Conn., U.S.A.) and the finely dispersed suspension was kept in an ice bath while in use. This sonicated cell suspension was employed for the assay of the following enzymatic activities: alkaline phosphatase (Enzyme Commission, EC, number 3.1.3.1), acid phosphatase (EC 3.1.3.2), $\beta$-galactosidase (EC 3.2.1.23), $\beta$-glucuronidase (EC 3.2.1.31) and lipase (a $\beta$-naphthyl laurate hydrolase, see Results). For the NBT test the cell samples were freshly prepared and received a somewhat different treatment as indicated below.

\section{QUANTITATIVE NITROBLUE TETRAZOLIUM (NBT) TEST (Baehner and Nathan, 1968)}

A 20-ml sample of peripheral blood was collected in plastic disposable syringes containing 20 iu per $\mathrm{ml}$ of heparin. The syringe was inverted, and the red cells were sedimented for the next $2 \mathrm{~h}$ at $37^{\circ} \mathrm{C}$. The supernatant plasma was decanted through an 18-gauge needle bent to an angle of $90^{\circ}$ into siliconized 50 -ml glass centrifuge tubes. After 2 vols of $0.87 \%$ ammonium chloride were added to the plasma, the tubes were inverted 5 times and centrifuged immediately thereafter for $5 \mathrm{~min}$ at $1400 \mathrm{rev} / \mathrm{min}$ (radius $=16 \mathrm{~cm}$ ) at $4^{\circ} \mathrm{C}$. The supernatant plasma was aspirated and the cell pellet was washed twice with Krebs-Henseleit bicarbonate buffer, pH 7.4 (Dawson, 1969), containing 0.2\% of glucose. The number of leucocytes per ml was calculated and diluted to $2.0 \times 10^{6}$ per $\mathrm{ml}$. To duplicate siliconized $15-\mathrm{ml}$ conical centrifuge tubes the following were added: $0.4 \mathrm{ml}(0.35 \mathrm{ml}$ in tubes containing latex particles) of the buffer, $0.1 \mathrm{ml}$ of $0.01 \mathrm{M}$ potassium cyanide, $0.4 \mathrm{ml}$ of $0.85 \%$ sodium chloride containing $0.1 \%$ NBT (Sigma N 6876), and $0.05 \mathrm{ml}$ of washed $0.8 \mu \mathrm{m}$ latex spherules in the tubes designated for phagocytosis. The duplicate tubes labelled "resting" did not contain latex particles. This mixture was incubated in a water bath at $37^{\circ} \mathrm{C}$ for $15 \mathrm{~min}$, then, $0.1 \mathrm{ml}$ of the previously prepared cell suspension was added to each tube. The reaction was allowed to proceed for $15 \mathrm{~min}$, then it was stopped by the addition of $2.0 \mathrm{ml}$ of $2.5 \mathrm{~N} \mathrm{HCl}$. The tubes were then centrifuged at $2000 \mathrm{rev} / \mathrm{min}$ for $15 \mathrm{~min}$. The supernatant was poured off and the sediment was extracted for $20 \mathrm{~min}$ with $4.0 \mathrm{ml}$ of pyridine in a boiling-water bath under an exhaust hood. The tubes were centrifuged again at $2000 \mathrm{rev} / \mathrm{min}$ for $15 \mathrm{~min}$, and the optical density $(D)$ of the purple colour of the reduced NBT was determined in a spectrophotometer at $515 \mathrm{~nm}$, against a pyridine blank. Resting and phagocyting values were obtained and the difference (increment in $D$ per 15 min per million leucocytes) was calculated.

\section{LIPASE (adapted from Nachlas and Seligman, 1949)}

In $16 \times 150 \mathrm{~mm}$ test tubes, 2.0 million leucocytes in $0.5 \mathrm{ml}$ of physiological saline solution (PSS) were incubated at $37^{\circ} \mathrm{C}$ for $60 \mathrm{~min}$ with $3.0 \mathrm{ml}$ of $\beta$-naphthyl laurate substrate $(10 \mathrm{mg}$ of $\beta$-naphthyl laurate, Sigma N 9375, were dissolved in $10 \mathrm{ml}$ of acetone, added through a submerged pipette into $50 \mathrm{ml}$ of an agitated solution consisting of $0.06 \mathrm{M}$ veronal buffer,

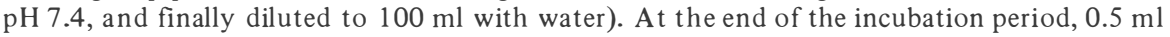
of a freshly prepared solution containing $2.0 \mathrm{mg}$ of Naphthanil Diazo Blue B (NDBB, Sigma D 3502) were added and the tubes were shaken. After 3 min the diazoreaction was stopped by adding $0.5 \mathrm{ml}$ of $40 \%$ trichloroacetic acid (TCA), and the colour was extracted with $5.0 \mathrm{ml}$ of ethyl acetate. The latter was cleared by a brief centrifugation and its $D$ was read immediately thereafter at $540 \mathrm{~nm}$ against a blank without enzyme.

\section{ALKALINE PHOSPHATASE (adapted from Manning et al., 1966)}

In $16 \times 150 \mathrm{~mm}$ test tubes, 6.0 million leucocytes in $0.1 \mathrm{ml}$ of PSS and $1.0 \mathrm{ml}$ of the stock buffered substrate [see (a)] were incubated for $60 \mathrm{~min}$ at $37^{\circ} \mathrm{C}$. At the end of the incubation time, $4.0 \mathrm{ml}$ of glycine buffer, $\mathrm{pH} 11.2$ [see (b)], were added to develop colour (the final $\mathrm{pH}$ of the reaction mixture was around 10.7). After thorough mixing, the tubes were centrifuged at $2000 \mathrm{rev} / \mathrm{min}$ for $10 \mathrm{~min}$ and the $D$ was read at $550 \mathrm{~nm}$ using the control without enzyme as the blank. (a) The stock buffered substrate contained $1.968 \mathrm{~g}$ of Tris (hydroxymethyl) aminomethane (Sigma T 1503), $30 \mathrm{mg}$ of sodium phenolphthalein diphosphate (Sigma P 9875), $100 \mathrm{mg}$ of magnesium sulphate, and $700 \mathrm{mg}$ of gelatin (Difco B 143). The pH was adjusted to 
9.6 and the volume brought to $100 \mathrm{ml}$. (b) The glycine buffer, pH 11.2, was prepared by dissolving $9.9 \mathrm{~g}$ of glycine, $7.19 \mathrm{~g}$ of $\mathrm{NaCl}$ and $40 \mathrm{~g}$ of sodium pyrophosphate (Sigma $\mathrm{T} \mathrm{6379)} \mathrm{in}$ $900 \mathrm{ml}$ of distilled water. While stirring, sufficient $30 \% \mathrm{NaOH}$ (approximately $17 \mathrm{ml}$ ) was added to adjust the $\mathrm{pH}$ to 11.2 and the volume brought to $1000 \mathrm{ml}$.

\section{ACID PHOSPHATASE (adapted from Seligman et al., 1951)}

In $16 \times 150 \mathrm{~mm}$ test tubes, the following were incubated for $30 \mathrm{~min}$ at $38^{\circ} \mathrm{C}: 2.8 \mathrm{ml}$ of $0.1 \mathrm{M}$ acetate buffer ( $\mathrm{pH} 5.1)$ containing 1.0 million leucocytes, $0.1 \mathrm{ml}(0.15 \mathrm{mg})$ of $\beta$-naphthyl phosphate (Sigma N 7375) and $0.1 \mathrm{ml}(1.0 \mathrm{mg})$ of $\mathrm{MnCl}_{2}$. After $1.0 \mathrm{ml}$ was removed to check the $\mathrm{pH}$, the reaction was stopped by adding $2.5 \mathrm{ml}$ of $0.05 \mathrm{M}$ veronal buffer $(\mathrm{pH} 8.5)$ which brought the $\mathrm{pH}$ of the reaction mixture to about 7.4. Diazocoupling was performed by adding $0.5 \mathrm{ml}$ of NDBB reagent $(80 \mathrm{mg}$ in $20 \mathrm{ml}$ of cold water) prepared just before use. After $3 \mathrm{~min}$ the reaction was stopped with $0.5 \mathrm{ml}$ of $40 \%$ TCA and the colour was extracted with $6.0 \mathrm{ml}$ of ethyl acetate. This was cleared by centrifugation $(2000 \mathrm{rev} / \mathrm{min}, 15 \mathrm{~min})$ and its $D$ was read immediately thereafter at $540 \mathrm{~nm}$ against a blank without enzyme.

\section{$\beta$-GALACTOSIDASE (adapted from Yarborough et al., 1967)}

Test tubes containing the following were incubated for $1 \mathrm{~h}$ at $38^{\circ} \mathrm{C}: 1.0 \mathrm{ml}$ of PSS containing 8.0 million leucocytes, $1.5 \mathrm{ml}$ of $0.1 \mathrm{M}$ phosphate citrate buffer $(\mathrm{pH} 4.1)$ and $0.5 \mathrm{ml}$ of $O$-nitrophenyl- $\beta$-D-galactoside (4.5 mg per ml, Sigma N 1127). At zero and $1 \mathrm{~h}, 1.0-\mathrm{ml}$ samples were removed, mixed with $1.0 \mathrm{ml}$ of $5 \% \mathrm{TCA}$, and centrifuged $(2000 \mathrm{rev} / \mathrm{min}, 15 \mathrm{~min})$. One and a half $\mathrm{ml}$ of sodium hydroxide-glycine reagent were added to $1.5 \mathrm{ml}$ of the supernatant fluid. The reagent contained $0.4 \mathrm{M}$ glycine and $0.8 \mathrm{M} \mathrm{NaOH}$ in amounts required to have a $\mathrm{pH}$ of 11.4. The resulting yellow colour was read at $420 \mathrm{~nm}$ against a blank without enzyme.

\section{$\beta$-GLUCURONIDASE (Yarborough et al., 1967)}

Test tubes containing 3.0 million leucocytes in $1.2 \mathrm{ml}$ of PSS, $1.5 \mathrm{ml}$ of $0.1 \mathrm{M}$ acetate buffer $(\mathrm{pH} 4.5)$ and $0.3 \mathrm{ml}$ of $0.01 \mathrm{M}$ phenolphthalein- $\beta$-glucuronic acid (Sigma 105-4, $\mathrm{pH} 7.0$ ), were incubated for $2 \mathrm{~h}$ at $38^{\circ} \mathrm{C}$. After $1.0 \mathrm{ml}$ was removed to check the $\mathrm{pH}, 2.0 \mathrm{ml}$ of $5 \%$ TCA were added and the tubes were centrifuged $(2000 \mathrm{rev} / \mathrm{min}, 15 \mathrm{~min})$. Two millilitres of alkaline reagent were added to $1.0 \mathrm{ml}$ of the supernatant. The reagent contained $1.0 \mathrm{M}$ glycine and $0.4 \mathrm{M} \mathrm{NaOH}$, approximately $1: 4$, so that the $\mathrm{pH}$ was 10.4 . The resulting purple colour was read at $540 \mathrm{~nm}$ in a photocolorimeter against a blank without enzyme. Zero hour samples were consistently colourless as reported by Yarborough et al. (1967).

\section{ENZYMATIC ACTIVITIES}

One unit was arbitrarily defined as the amount of enzyme (number of disrupted leucocytes) that should cause an absorbance increase of 1.00 under the conditions of the assays. All determinations were performed in the 0.1-0.4 range where linearity was held. The specific activity was defined as the total units of activity per mg of protein. Protein was determined by the Lowry procedure (1951), using bovine serum albumin as a reference solution.

\section{STATISTICAL ANALYSIS}

The Student $t$-test for small samples was used to calculate the level of significance $(P)$ of every determination done between normal and leprosy populations. Because of the natural internal variation within groups a correction was introduced: the control group was randomly divided into 2 subgroups and, for each assay performed, the Student $t$-test was used to calculate the level of significance between subgroups. This vilue served to correct the $P$-values between control and leprosy groups. In this paper, the reported $P$-values are the corrected ones. 


\section{Results}

\section{NITROBLUE TETRAZOLIUM TEST}

Eighteen patients with lepromatous leprosy and 18 healthy (control) individuals were included in the test. Both control $(N)$ and leprosy $(L)$ populations were able to reduce the oxidized NBT dye (Fig. 1). Although a certain difference between $L$ and $N$ groups could be observed, this difference resulted in non-statistical significance. Table 1 shows the activity found in each

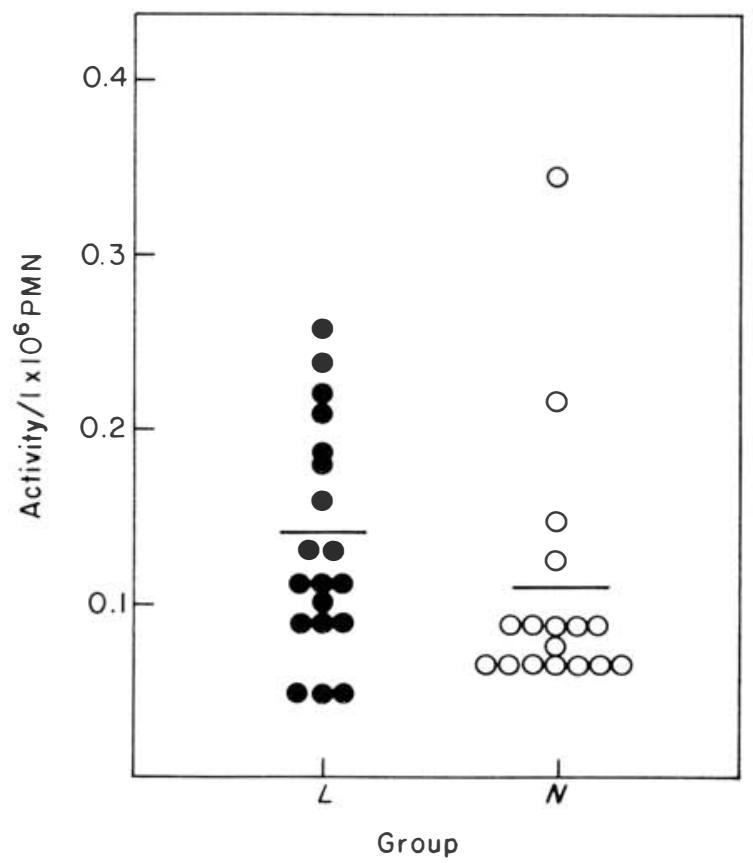

Fig. 1. NBT reduction by leucocytes from patients with lepromatous leprosy $(L)$ and by leucocytes from normal individuals $(N)$. The activity is given as the increment in $D$ (phagocytosis minus resting) per one million leucocytes, per $15 \mathrm{~min}$ incubation at $37^{\circ} \mathrm{C}$. Horizontal lines are the mean value.

group (range, mean value \pm the standard error, and the $P$-value). The activity is given as the increment in $D_{515} \mathrm{~nm}$ (phagocytosis minus resting) per one million leucocytes, per 15 -min incubation at $37^{\circ} \mathrm{C}$. It can be deduced that, as a group, lepromatous patients are not defective in their circulating phagocytic cells' ability to endocytose latex spherules, nor in their ability to undergo the oxidative changes that accompany the phagocytic process and which permit, among other things the reduction of the oxidized NBT dye. 
TABLE 1

Reduction of the Nitroblue Tetrazolium dye by leucocytes from healthy and lepromatous individuals

\begin{tabular}{cccccc}
\hline \multirow{2}{*}{ Group } & $\begin{array}{c}\text { No. of } \\
\text { individuals }\end{array}$ & Range & Activity* & \\
& & & & & \\
Leprosy $(L)$ & 18 & $0.051-0.262$ & 0.141 & 0.015 & 0.5 \\
Normal $(N)$ & 18 & $0.042-0.351$ & 0.110 & 0.017 & \\
\hline
\end{tabular}

* Increment in $D$ (phagocytosis minus resting) per one million leucocytes, per $15 \mathrm{~min}$ incubation at $37^{\circ} \mathrm{C}$. Other conditions were as described under Materials and Methods.

\section{LEUCOCYTE HYDROLASES}

Figure 2 shows the results when the alkaline phosphatase (AlPh), the acid phosphatase $(\mathrm{AcPh})$, the $\beta$-glucuronidase $(\beta$-Glu), the $\beta$-galactosidase $(\beta$-Gal) and the lipase (Lip) activities were assayed. It can be observed that, for every enzyme, the cell population derived from the leprosy group $(L)$ showed a somewhat higher activity than that found in the normal group $(N)$. However, when these differences were analyzed they resulted in non-statistical significance. The mean specific activity (total units of activity per mg of protein), the standard error, the number of samples assayed and the $P$-value, are given in Table 2 . Each assay was performed at least twice and the reported results are those obtained with an optimal number of cells as determined by preliminary experiments. It is clear that there is not a significant difference between groups $L$ and $N$ for most of the assayed enzymatic activities although, in the case of the lipase, a certain difference was observed as judged from the $P$-values: 0.05 (uncorrected) and 0.1

TABLE 2

Some enzymatic activities present in leucocytes from patients with lepromatous leprosy in comparison with those found in healthy individuals

\begin{tabular}{|c|c|c|c|}
\hline \multirow[b]{2}{*}{ Enzyme } & \multicolumn{2}{|c|}{ Specific activity in $*$} & \multirow[b]{2}{*}{$P$} \\
\hline & Leprosy & Normals & \\
\hline Alkaline phosphatase & $\begin{array}{c}1.540 \pm 0.619 \\
(11)\end{array}$ & $\begin{array}{c}0.738 \pm 0.220 \\
\text { (13) }\end{array}$ & 0.5 \\
\hline Acid phosphatase & $\begin{array}{c}3.290 \pm 0.897 \\
(12)\end{array}$ & $\begin{array}{c}2.449 \pm 0.322 \\
\text { (12) }\end{array}$ & 0.9 \\
\hline$\beta$-Glucuronidase & $\begin{array}{c}0.410 \pm 0.053 \\
(12)\end{array}$ & $\begin{array}{c}0.365 \pm 0.028 \\
\text { (11) }\end{array}$ & 0.6 \\
\hline Lipase & $\begin{array}{c}1.472 \pm 0.272 \\
(10)\end{array}$ & $\begin{array}{c}0.800 \pm 0.095 \\
\text { (11) }\end{array}$ & 0.1 \\
\hline$\beta$-Galactosidase $\dagger$ & 0.088 & $\begin{array}{l}0.095 \\
(14)\end{array}$ & \\
\hline
\end{tabular}

* The specific activity is given as the total units of activity per $\mathrm{mg}$ of protein. The mean value and the standard error are shown and the number of samples analyzed is given in parenthesis.

$\dagger$ Because of the small number of samples included (see text) neither the standard error nor the $P$-value were calculated. 


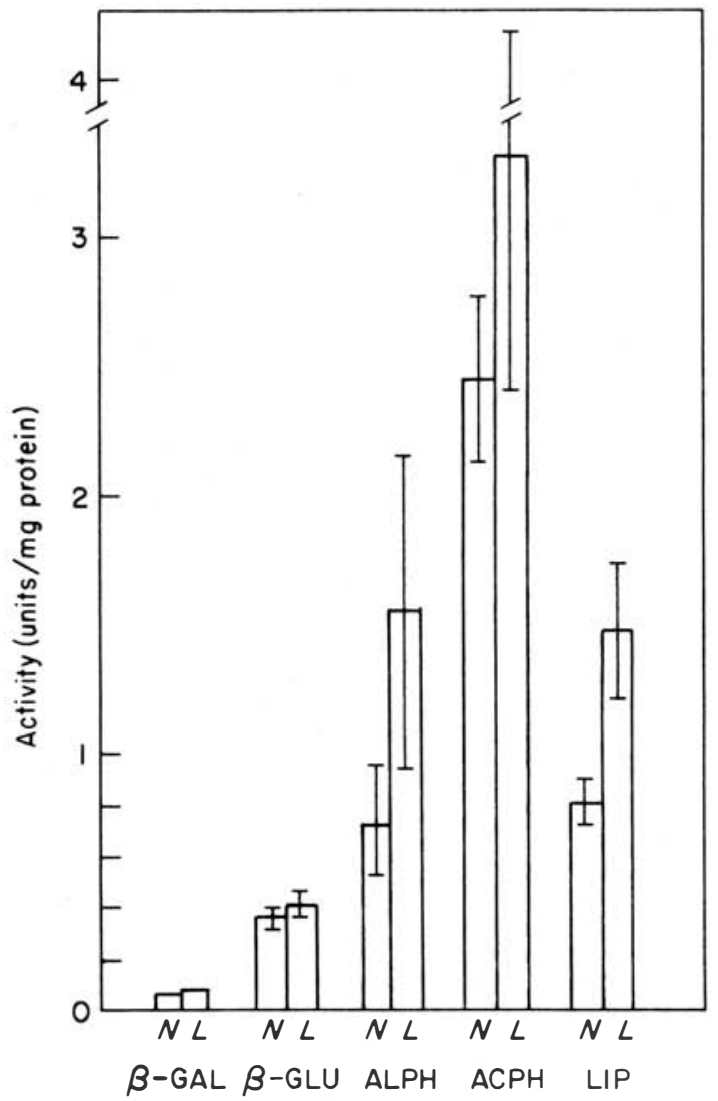

Fig. 2. Levels of $\beta$-galactosidase, $\beta$-glucuronidase, alkaline phosphatase, acid phosphatase and lipase in leucocytes from patients with lepromatous leprosy $(L)$ and normal individuals $(N)$. The activities are given as the total units per mg of protein (see Materials and Methods). The mean value and the standard error are shown.

(corrected). Because several authors consider that the technique used in this study ( $\beta$-naphthyl laurate as the substrate; Nachlas and Seligman, 1949) is related with an esterase more than with a lipase, we are now using a natural complex substrate (coconut oil) and the results will be presented in a further communication. The assay for $\beta$-Gal required a large amount of cells. As described under Materials and Methods, 8.0 million leucocytes had to be used in the test and even with this number, $D$ readings lower than 0.10 were obtained. Although the mean specific activity in $L$ and $N$ groups showed no apparent difference, because of the small number of samples a statistical analysis was not possible.

\section{Discussion}

Some reports have previously appeared regarding the ability of PMN from leprosy patients to reduce the NBT dye (Lim et al., 1974b; Goihman-Yahr et al., 1975). This test has been used to measure the overall oxidative changes that 
follow the phagocytic process and which are related to the normal function of phagocytes. These changes include an increase in oxygen and glucose consumption, an increase in the production of hydrogen peroxide and other bactericidal peroxides, the activation of the "hexose monophosphate shunt", and other related changes (see DeChatelet, 1975, for a recent review). Under these conditions, reduced NAD and NADP co-factors reach high levels and they can be used, among other things, to reduce the oxidized NBT dye, providing adequate levels of "diaphorase" (the total of all enzymes that can catalyze a reaction between NBT dye and reduced pyridine nucleotides to give the insoluble blue formazan) are present. Compared with controls, leucocytes from lepromatous patients have normal levels of both reduced co-factors (NADH and NADPH) and "diaphorase" activity as can be deduced from their ability to efficiently reduce the oxidized NBT dye (Lim et al., 1974b; Goihman-Yahr, 1975; this paper, Fig. 1).

Peripheral leucocytes of leprosy patients are not depressed in their ability to produce normal levels of lysosomal hydrolytic enzymes. This seems to be a logical finding because (a) the leprosy bacillus does not primarily parasitize polymorphonuclear leucocytes but monocytic leucocytes and tissue macrophages, and (b) the PMN is the predominant phagocytic cell in peripheral blood. On the other hand, it has been demonstrated that only a small proportion $(0.1-0.3 \%)$ of the blood PMN leucocytes of lepromatous patients contain bacilli, but the number of bacilli per cell is usually 1 and rarely 2 or 3 , while up to $3 \%$ of the blood monocytes contained a number of bacilli which was between 1 and more than 10 , per cell.

Probably the short half-life of PMN leucocytes (about $6 \mathrm{~h}$ in circulation and 1-2 days in tissues) and their tendency to "commit suicide" while engaged in phagocytic processes, could be a simplistic explanation for the fact that this type of cell is usually not shown to be more broadly parasitized by the long-lived mycobacteria. An alternate explanation could be based on the fact that although PMN leucocytes possess immunoglobulin-receptors (Wardley et al., 1976; Zighelbaim et al., 1976), they do not seem to have both immunoglobulin $\left(\operatorname{IgG}_{1}\right.$ and $\left.\mathrm{IgG}_{3}\right)$ and complement $\left(\mathrm{C}_{3 \mathrm{~b}}\right)$ receptors which make the mononuclear phagocytes, highly phagocytic cells.

The mean value for each enzymatic activity was slightly higher within the patients' group although this difference, for most of the cases, was not statistically significant. Therefore, from our results it was concluded that the leucocyte population from lepromatous patients, is not deficient in the activity of the studied lysosomal enzymes, at least under our conditions of assay. Even when parasitized leucocytes could have impaired metabolic or enzymatic activities, the defect might not reflect in the overall activity of the leucocyte population due to dilution, as only about $0.3 \%$ of the total leucocyte population in untreated patients has been found to be parasitized by acid-fast bacilli (Drutz et al., 1972, 1974).

In relation to the lipase activity, although a complex lipid substrate was not used, we believe that because of the waxy components of the wall structure of $M$. leprae and other mycobacteria, it is an enzyme that must be studied in more detail and with a more appropriate methodology. Other enzymatic activities and oxidative metabolic changes have to be studied to definitively state that circulating leucocytes of lepromatous patients behave in an essentially normal manner as compared with leucocytes from healthy individuals. 


\section{Acknowledgements}

O. Rojas-Espinosa, J. E. García and S. Estrada, are fellow holders from the Comisión de Operación y Fomento de las Actividades Académicas del Instituto Politécnico Nacional, México. We are deeply in debt to Drs F. Latapí and A. Saúl, from the Centro Dermatológico Pascua at Mexico City, for letting us work with their patients, and to Miss Theresa Dolan for her help in the preparation of the manuscript. Financial support was obtained from the W.H.O. and from the Conacyt, México.

\section{References}

Baehner, R. L. and Nathan, D. G. (1968). Quantitative nitroblue tetrazolium test in chronic granulomatous disease. N. Engl. J. Med. 278, 971.

Barbieri, T. A. and Correa, W. M. (1967). Human macrophage culture. The leprosy prognostic test (LPT). Int. J. Lepr. 35, 377.

Beiguelman, B. (1967). Leprosy and genetics. A review of past research with remarks concerning future investigations. Bull. Wld Hlth Org. 37, 461.

Convit, J., Avila, J. L., Goihman, M. and Pinardi, M. E. (1972). A test for the determination of competency in clearing bacilli in leprosy patients. Bull. Wld Hlth Org. 46, 821.

Convit, J., Pinardi, M. E., Rodríguez-Ochoa, G., Ulrich, M., Avila, J. L. and Goihman, M. (1974). Elimination of Mycobacterium leprae subsequent to local in vivo activation of macrophages in lepromatous leprosy by other mycobacteria. Clin. exp. Immun. 17, 261.

Cooper, M. R., DeChatelet, L. R., McCall, C. E., LaVia, M. F., Spurr, C. L. and Bahener, R. L. (1972). Complete deficiency of leukocyte glucose-6-phosphate dehydrogenase with defective bactericidal activity. J. Clin. Invest. 51, 769.

Dawson, R. M. C., Elliott, D. C., Elliott, W. H. and Jones, K. M. (1969). Data for Biochemical Research, 2nd ed. p. 507: Oxford University Press.

DeChatelet, L. R. (1975). Oxidative bactericidal mechanisms of polymorphonuclear leukocytes. J. Infect. Dis. 131, 295.

Drutz, D. J., Chen, T. S. N. and Lu, W. H. (1972). The continuous bacteremia in lepromatous leprosy. N. Engl. J. Med. 287, 159.

Drutz, J. D., O'Neill, S. M. and Levy, L. (1974). Viability of blood borne Mycobacterium leprae. J. Infect. Dis. 130, 288.

Dwyer, J. M., Bullock, W. E. and Fields, J. P. (1973). Disturbance of the blood T: B lymphocyte ratio in lepromatous leprosy. Clinical and immunologic correlations. N. Engl. J. Med. 288, 1036.

Godal, T., Myklestad, B., Samuel, D. R. and Myrvang, B. (1971a). Characterization of the cellular immune defect in lepromatous leprosy: A specific lack of circulating Mycobacterium leprae-reactive lymphocytes. Clin. exp. Immunol. 9, 821 .

Godal, T., Rees, R. J. W. and Lamvik, J. O. (1971b). Lymphocyte-mediated modification of blood-derived macrophage function in vitro: Inhibition of growth of intracellular mycobacteria with lymphokines. Clin. exp. Immunol. 8, 625 .

Goihman-Yahr, M., Rodríguez-Ochoa, G., Aranzazu, N. and Convit, J. (1975). Polymorphonuclear activity in leprosy. I. Spontaneous and endotoxin-stimulated reduction of nitroblue tetrazolium: effects of serum and plasma on endotoxin-induced activation. Clin. exp. Immunol. 20, 257.

Hanks, J. H. (1947). The fate of leprosy bacilli in fibroblast cultivated from macular and tuberculoid lesions. Int. J. Lepr. 15, 31.

Holmes, B., Page, A. R. and Good, R. A. (1967). Studies of the metabolic activity of leukocytes from patients with a genetic abnormality of phagocytic function. J. Clin. Invest. 46, 1422.

Job, C. K. and Karat, A. B. A. (1967). In Hart, P. D. and Rees, R. J. W. Lepromin and Kveim antigen reactivity in man, and their relation to tuberculin reactivity. Brit. med. Bull. 23, 80.

Kaplan, E. L., Laxdal, T. and Quie, P. G. (1968). Studies of polymorphonuclear leukocytes from patients with chronic granulomatous disease of childhood: bactericidal capacity for streptococci. Pediatrics 41, 591 . 
Lim, S. D., Kiszkiss, D. F., Jacobson, R. R., Choi, Y. S. and Good, R. A. (1974a). Thymus-dependent lymphocytes of peripheral blood in leprosy patients. Infect. Imriun. 9, 394.

Lim, S. D., Kim, W. S., Kim, C. S., Good, R. A. and Park, B. H. (1974b). NBT responses of neutrophils and monocytes in leprosy. Int. J. Lepr. 42, 150.

Lowry, H. O., Rosebrough, N. J., Farr, A. L. and Randall, R. J. (1951). Protein measurement with the Folin-phenol reagent. J. Biol. Chem. 193, 265.

Manning, J. P., Steinetz, B. G., Babson, A. L. and Butler, M. C. (1966). A simple and reliable method for estimation of alkaline phosphatase in tissue homogenates. Enzymol. Acta biocatal. 31, 309.

Mitsuda, K. (1953). On the value of a skin reaction to a suspension of leprous nodules. Int. J. Lepr. $21,347$.

Nachlas, M. M. and Seligman, A. M. (1949). Evidence for the specificity of esterase and lipase by the use of three chromogenic substrates. J. Biol. Chem. 181, 343.

Seligman, A. M., Chauncey, H. H., Nachlas, M. M., Manheimer, L. H. and Ravin, H. A. (1951). The colorimetric determination of phosphatases in human serum. J. Biol. Chem. 190, 7.

Stossel, T. P., Root, R. K. and Vaughan, M. (1972). Phagocytosis in chronic granulomatous disease and the Chediak-Higashi syndrome. N. Engl.J. Med. 286, 120.

Turk, J. L. (1969). Cell-mediated immunological processes in leprosy. Bull. Wld Hlth Org. 41, 779.

Turk, J. L. and Waters, M. F. R. (1969). Cell-mediated immunity in patients with leprosy. Lancet 2, 243 .

Wardley, R. C., Rouse, B. T. and Babiuk, L. A. (1976). Antibody-dependent cytotoxicity mediated by neutrophils: A possible mechanism of antiviral defense. J. Reticuloendothel. Soc. $19,323$.

Yarborough, D. J., Meyer, O. T., Dannenberg, A. M. and Pearson, B. (1967). Histochemistry of macrophage hydrolases. III. Studies on $\beta$-galactosidase, $\beta$-glucuronidase and aminopeptidase with indolyl and naphthyl substrates. J. Reticuloendothel. Soc. 4, 390.

Zighelbaim, J., Gale, R. P. and Kedar, E. (1976). Polymorphonuclear leukocyte Fc receptors in antibody-dependent cellular cytotoxicity (ADCC). Transplantation 21, 524. 